\title{
Livelihoods Pattern of "Negede Weyto" Community in Lake Tana Shore, Bahir Dar Ethiopia.
}

Ajala O.A*.

\begin{abstract}
Livelihoods is function of location, certain locations possessed resources (physical and human) and provides better opportunities to inhabitants than others. People living in marginal lands such as deserts, delta and riverine areas, flood plains and mountainous area with high slope gradient have problems in sustaining their livelihoods. This Paper examined the livelihoods pattern of "Negede Weyto" community, a small tribe living in the marginal land along the Lake Tana shore line, Bahir Dar Ethiopia. Using 123 respondents and 4 FGD groups for the survey and analyzed with simple statistical methods and regression; the study revealed that their livelihoods is seriously exposed to vulnerability factors which are external and beyond what they can address by their limited capacities. It thus calls for intervention by Government and NGOs to rescue the vulnerable community.
\end{abstract}

Key Words: Negede Weyto, Lake Tana, Livelihoods, Vulnerability.

\section{Introduction}

ivelihoods is an aggregate
measure of how people or a given population ( as small as a household of a single person) make their living within the limit imposed by the environmental, social, economic and political conditions of the society within which they live. This determines the totality of human welfare of a household at the micro level, and a community, a region or a nation at macro level.

People are considered to be 'poor' if they do not have sufficient resources or they lack access to resources necessary to be able to provide food and water, shelter, clothing, warmth and other necessities to sustain life for themselves or for their family, i.e. a life of unsustainable livelihoods. According to UNDP (1990) poor people are deprived of the basic opportunities to lead a long healthy and creative lives as a result of the mal-distribution of resources, assets and human capacities, thus one distinguishing characteristics of nearly all who live unsustainable livelihoods is marginality.

Livelihoods is function of location, certain locations possessed resources (physical and human) and provides better opportunities to inhabitants than others. For instance, due to the pattern of socio-economic development in the less developed countries, urban centres provide more opportunities for better livelihoods than the rural areas. In the rural areas as well certain locations may provide better opportunities or constraints to livelihoods due to areal differentiation of the physical and climatic conditions, apart from the institutional factors prevailing in such region or nation. For instance, a location of relatively flat terrain with fertile soils will provide opportunity for better livelihoods to people than marginal lands such as deserts, delta and riverine areas, flood plains and mountainous area with high slope gradient.

Ethiopia is adjudged as one of the poorest countries of the World, with very poor performance in the Human Development Indicators (HDI). As at 2005 the HDI for Ethiopia was 0.406 , which gives the country a rank of $169^{\text {th }}$ out of 177 countries and the Human Poverty Index (HPI-1) value of 54.9 for Ethiopia, ranks $105^{\text {th }}$ among 108 developing countries for which the index has been calculated.

The Human Poverty Index for developing countries (HPI-1) focuses on the proportion of people below a threshold level in the same dimensions of human development as the human development index - living a long and healthy life, having access to education, and a decent standard of living. By looking beyond income deprivation, the HPI-1 represents a multi-dimensional alternative to the $\$ 1$ a day (PPP US\$) poverty measure. The HPI-1 measures severe deprivation in health by the proportion of people who are not expected to 
survive age 40. Education is measured by the adult illiteracy rate. And a decent standard of living is measured by the un-weighted average of people without access to an improved water source and the proportion of children under age 5 who are underweight for their age (UNDP, 2008).

Ethiopia, is a country prone to natural disasters which include drought, famine, floods, landslides and extreme climatic conditions, due to the rugged topography of the country. In Ethiopia, pattern of livelihoods differs from region to region and within a region there exists variations depending on the location, either urban or rural. In the rural areas as well, pattern of livelihoods varies. Of serious concern are the people living in the marginal lands such as deserts, flood plains and shore line of major lakes in the country. People living in such marginal lands can be regarded as the poorest of the poor, yet they make their living.

It is against this background that this study focuses on the understanding of the pattern of rural livelihoods of people living in marginal lands, taking Lake Tana shore line community in Bahir Dar, Ethiopia as a case study. In order to achieve this, the study was designed to address the following specific objectives:

(a)

To examine the means of livelihoods available to the people in this marginal area in terms of resources, assets and capability.

(b) To examine the types of vulnerability or constraint faced by the people, and

(c) To identify the major intervention need of the people based on their collective decision.

\section{Concept of Sustainable Livelihoods}

The concept of sustainable livelihoods is a reference point for a wide range of people involved in different aspects of development studies, policy formulation and planning. As analysts point out, there are two broad approaches to defining livelihoods. One has a narrower economic focus on production, employment and household income. The other takes a more holistic view which unites concepts of economic development, reduced vulnerability and environmental sustainability while building on the strengths of the rural poor (Shackleton et al, 2000).

Although there are differences of interpretation and different variations of livelihoods framework, they all build on earlier development theory. These include aspects of the integrated rural development planning (IRDP) approaches of the 1970s; food security initiatives during the 1980s; rapid rural appraisal (RRA); participatory rural appraisal (PRA); farming systems research; gender analysis; new understanding of poverty and well-being; risk and vulnerability assessment and agrarian reform.

Many earlier development approaches assumed that rural society was homogeneous (in other words, that there was no differentiation between households in rural areas) and that households had single-purpose economies (in other words, that they only had one way of making a living). Also, the factor of areal differentiation in the rural areas due to physical and climatic conditions was relegated to the background as of no effect. As a result, development agencies tended to focus on narrow, sectoral, production-orientated strategies that often bypassed those most at risk particularly people in the marginal lands. They also failed to recognise that poor households have multiple economic strategies (Turner, 1998).

Chambers and Conway (1992) developed a definition of livelihoods and the factors that make them sustainable which underpin all of the livelihoods frameworks currently being used:

A livelihood comprises of the capabilities, assets (stores, resources, claims and access) and activities required for a means of living: a livelihood is sustainable which can cope with and recover from stress and shocks, maintain and enhance its capabilities and assets, and provide sustainable opportunities for the next generation; and which contributes net benefit to other livelihoods at the local and global levels in the long and short term.

The Chambers and Conway definition was modified by DFID in 1999, as: 
A livelihood comprises the capabilities, assets (including both material and social resources) and activities required for a means of living. A livelihood is sustainable when it can cope with and recover from shocks and stresses and maintain and enhance its capabilities and assets both now and in the future whilst not undermining the natural resource base (Carney, 1999).

Other livelihoods definitions make people more central and are less concerned with precise terminology for different kinds of asset. They highlight issues of ownership, access and decision making. One of these definitions of livelihoods states:

People's capacity to generate and maintain their means of living, enhance their well-being and that of future generations. These capacities are contingent upon the availability and accessibility of options which are ecological, economic and political and which are predicated on equity, ownership of resources and participatory decision making (Titi and Singh, 1994).

Despite differences in emphasis by different practitioners, the livelihoods framework help s us to: identify (and value) what people are already doing to cope with risk and uncertainty; make the connections between factors that constrain or enhance their livelihoods on the one hand, and policies and institutions in the wider environment, and identify measures that can strengthen assets, enhance capabilities and reduce vulnerability.

The DFID livelihoods framework which is the most widely used sets out to conceptualise:

- How people operate within a vulnerability context that is shaped by different factors- shifting seasonal constraints (and opportunities), economic shocks and longer-term trends.

- How they draw on different types of livelihood assets or capital in different combinations which are influenced by: the vulnerability context, a range of institutions and processes, and how they use their asset base to develop a range of livelihood strategies to achieve desired livelihood outcomes.
DFID livelihood frameworks try to show how the different elements (all of which are highly dynamic) interrelate and influence one another (figure 1). The core concept of the framework is that it is people-centred which advocates that:

- Development policy and practice should flow from an understanding of the poor and their livelihoods strategies.

- The poor should directly contribute to determining development priorities and be able to influence the institutions and processes that impact on their lives.

- It is holistic in that is encourage analysis that cut across different sectos and recognises a range of actors and influences as well as multiple livelihood strategies and outcomes.

- It is dynamic in that it tries to understand change over time and the complex interplay between different factors.

- It starts from an analysis of strengths rather than needs and problems.

- It looks for and makes the linkages between micro and macro levels.

- It is concerned with sustainability in all its dimensions-social, economic, institutional and ecological.

From the view expressed above, an understanding of the livelihood pattern of the people as a base line evaluation is required if any meaningful intervention would be carried out to improve or enhance the livelihoods of any group of people. In the less developed countries of sub-Sahara Africa people living in the marginal lands are often neglected in rural development projects where as they are more vulnerable than others within the rural set up. Thus this study was carried out to bring to the fore the problems of sustainable livelihoods of one of such cases of people living in marginal lands as a pointer for policy makers and 
development practitioners to think of the poorest of the poor when talking sustainable livelihoods particularly in the developing countries.

\section{Study Area}

Amhara National Regional State, with Bahir Dar as the regional capital, is one of the nine regions in Ethiopia; located in the North western part of the country. It has a total land area of $161,828.40$ square kilometers, with a population of 17,266,383 as at 2005 (Amhara BFED, 2005). Amhara region is divided into eleven administrative zones; each is further divided into "Woreda" (administrative community). Amhara region is basically a rural region with 89 percent of its population in the rural areas while only 11 percent are urban dwellers. The region is quite homogeneous in terms of language (Amharic) and culture.

Bahir Dar is located within the central plateau of Ethiopian highlands, sharing the shore of Lake Tana, the source of Blue Nile a major tributary of River Nile which is the longest river in Africa. It lies at an altitude 1830 metres above sea level, with an average temperature in the range of $12-18^{0}$ centigrade and rainfall between $400-2000 \mathrm{~mm}$, usually from June to September (Figure 2).

Bahir Dar, has a population of 145,982 as at 2002, it is declared a special zone in Amhara region being the regional capital. It is the home of the Gojam tribe of Amhara. It has witnessed rapid urbanization and physical expansion in recent time due to rural-urban migration.

Lake Tana, is one of the largest inland water lakes in Africa with the total area of $3600 \mathrm{~km}^{2}$, stretching 75 kilometres North and South ,60 kilometres East-West and lying at about 1830 metres above sea level and having 14 metres maximum depth. It is along the shore line of the lake that a smaller tribe called "Negede Weyto" have their habitation and engaged in livelihoods activities (Amhara, 2005).

\section{Methodology}

The data used for this study were derived from primary sources. The primary data were gathered through the administration of questionnaire and Focus Group Discussion (FGD) designed for a livelihoods survey of the study area. Due to the disperse nature of the settlement, the community was divided into four zones. In administering the questionnaire, stratified random sampling method was used. The questionnaire contained 31 variables bordering demographic and livelihoods activities of the people as identified during the reconnaissance field work. A total of 123 respondents gave adequate information out of 140 questionnaires administered in the community. Also, four FGD was conducted in the four zones, this was done to get information that are communal and institutional which have impact either positive or negative on livelihoods activities of the people. The participants of the FGD were selected among the respondents; each group of 10 people is a mixture of both male and female, in the age range of 17 to 50 years. Simple statistical tools (percentages) and linear regression were used to analyze the data generated.

\section{Results and Discussions}

This section discussed the findings of the study, it is arranged in to sub-sections in order to reveal different aspects of livelihoods pattern as observed in the community. The sub- sections include general characteristics of the people, livelihoods assets, livelihoods activities, and factors of vulnerability. 


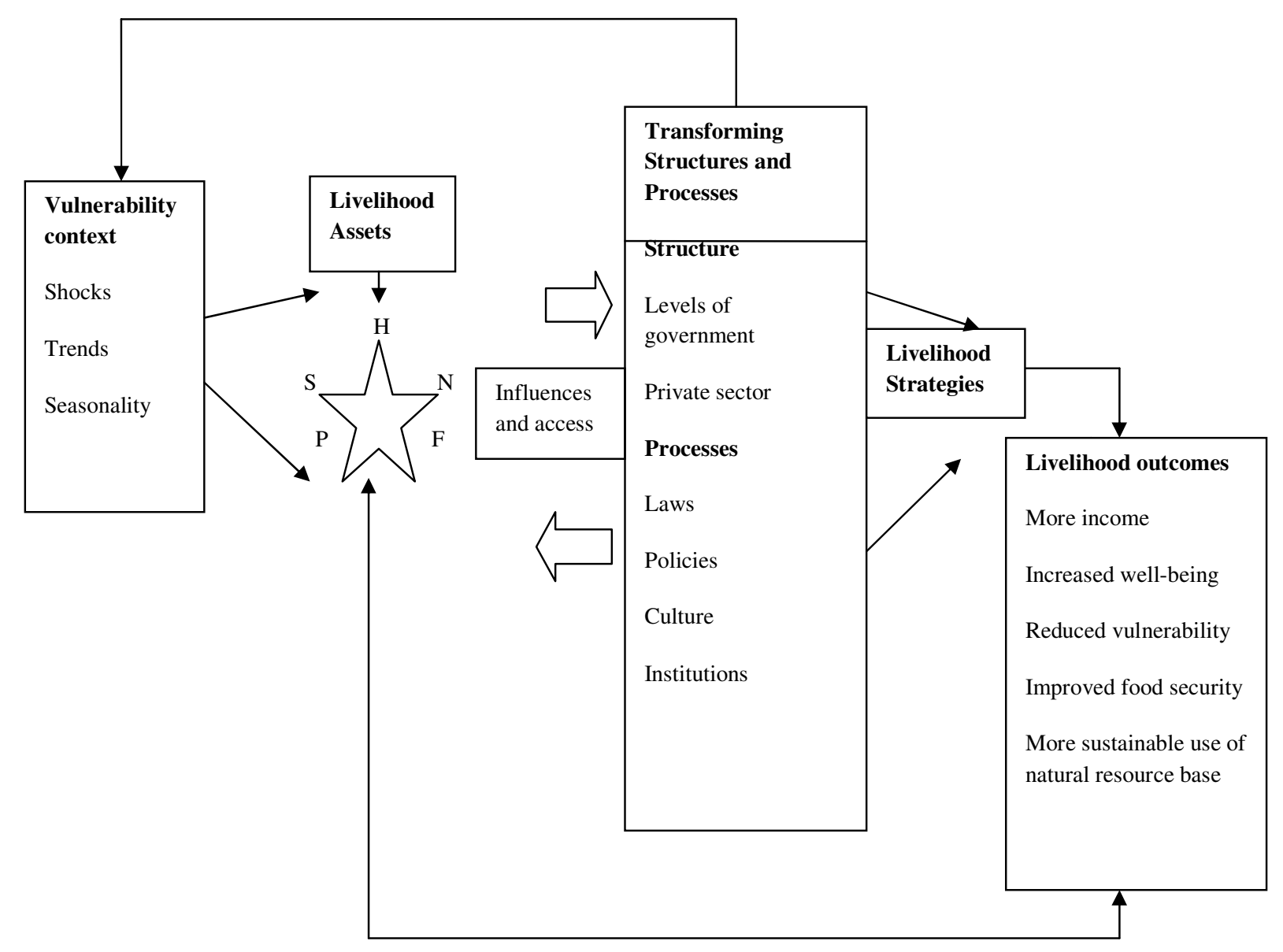

H- Human capital: the skills, knowledge, ability to labour and good health important to the ability to pursue livelihood strategies

P- Physical capital: the basic infrastructure (transport, shelter, water, energy and communication) and the production equipment and means that enable people to pursue livelihoods

S-Social capital: the social resources (networks, membership of groups, relationships of trust, access to wider institutions of society) upon which people draw in pursuit of livelihoods;

F-Financial capital: the financial resources which are available to people (whether savings, supplies of credit or regular remittances or pensions) and which provide them with different livelihood options; and

N-Natural capital: the natural resources stocks from which resources flows useful for livelihoods are derived (e.g. land, water wildlife, biodiversity, environmental resources).

Figure 1- The DFID Livelihoods Framework (Adapted from Rick et al 2002) 


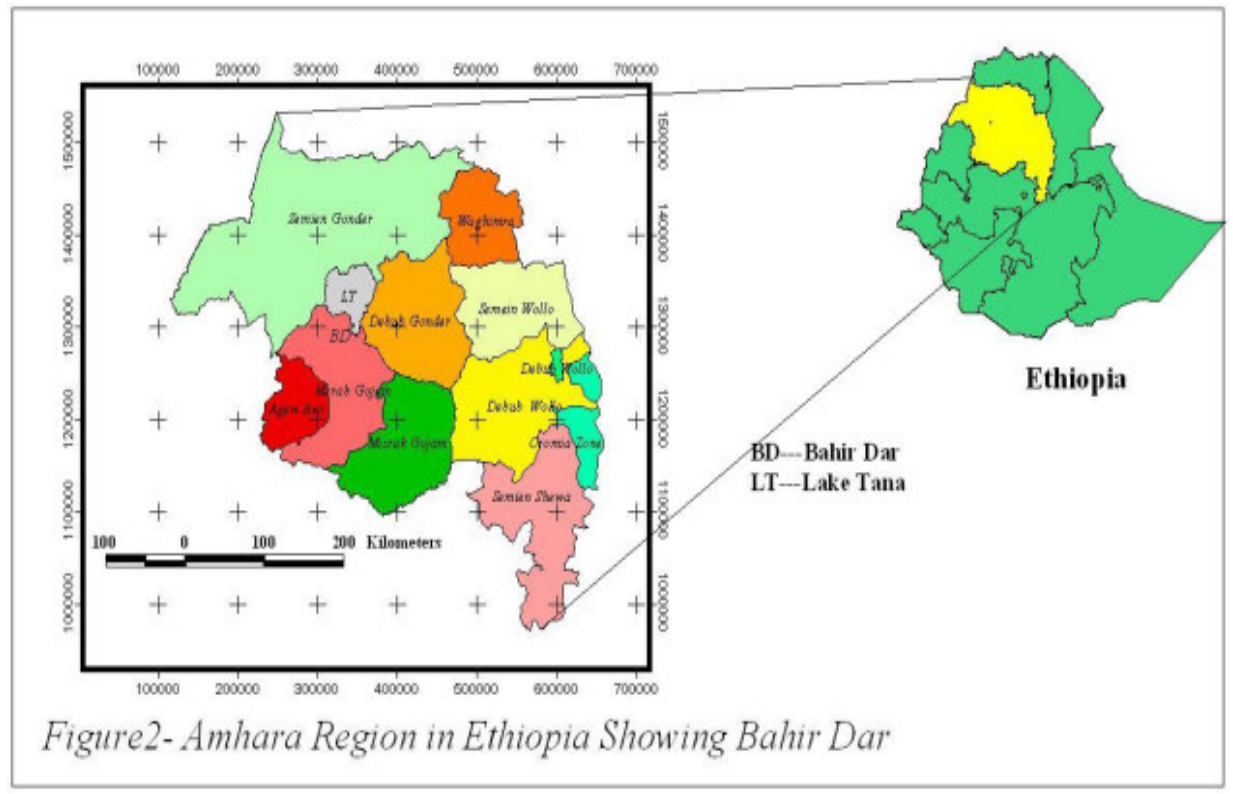

\section{General Characteristics of the Respondents}

The study reveals that most of the respondents were males with $77 \%$ and $23 \%$ of females. The preponderance of male above female indicated that male headed households are predominant in the study area, though there are sizable female headed households. The age range from 17 to above 50 years, while the marital status revealed that singles $15 \%$, married $61 \%$ and the remaining $24 \%$ are the group of widow/widowers, divorced and separated. The educational status revealed that $47.2 \%$ have no education at all, $26.8 \%$ attended between grade1- 4, 19.5\% attended grade 5-8, 5.7\% attended between grade 9-12 and only $0.8 \%$ have diploma. This is not surprising as the adult literacy rate (\% aged 15 and older) for the whole country was $35.9 \%$ and combined gross enrolment ratio for primary, secondary and tertiary education was $42.1 \%$ in 2005 . The Ethiopia population as at then (2005) was estimated to be more than 70 million, the second populous country in Africa after Nigeria. Number of children in each household varies from zero for those that are single with no dependants to more than five children. Households with at least three children is the highest with $28.5 \%$,households with one child, four children and more than five children constitute $13 \%$ each, $14.6 \%$ households have two children each, another $8.1 \%$ have at least five children, only $8.9 \%$ are singles without children or dependants, ( see Table 1).

\section{Livelihoods Assets}

DFID livelihoods framework identifies five livelihoods assets through which livelihoods activities are carried out for means of living. These are:

$>$ Human capital: the skills, knowledge, ability to labour and good health important to the ability to pursue livelihood strategies

Physical capital: the basic infrastructure ( education, health, transport, shelter, water, energy and communication,) and the production equipment and means that enable people to pursue livelihoods

$>$ Social capital: the social resources (networks, membership of groups, relationships of trust, access to wider institutions of society i.e. education, health) upon which people draw in pursuit of livelihoods;

Financial capital: the financial resources which are available to people (whether savings, supplies of credit or regular remittances or pensions) and which provide them with different livelihood options; and

$>$ Natural capital: the natural resources stocks from which resources flows useful for livelihoods are derived (e.g. land, water wildlife, biodiversity, environmental resources).

All these assets functions in an interrelated system for every household or individuals to 
be able to carry out livelihoods activities for means of living. Relating these assets to the "Negede Weyto" people, their human capital is limited to their personal ability as almost the entire population lack sufficient education which could give them the required knowledge to utilize other assets better for their means of livelihoods. Their inability to acquire knowledge can be blamed on the inability of the larger society (the institutional structure, i.e. the government) to provide for their education. Their personal ability is also limited by their health situations at different times and inadequate accessibility to health facilities. Other public social assets such as transport, safe drinking water, electricity and modern communication are barely inexistence; even where they exist they can not afford them because of their limited financial capital. However, the "Negede Weyto" people enjoy a network of traditional/ communal social capital in terms of support for each other in distress periods and communal work of helping each other in building construction/ reconstruction when the need arises. Their building materials are clay/ mud, wood and grass for the roofing, because of their environmental situation the life span of their buildings is short which requires reconstruction on the average of five years.

Natural capital available to the people are the Lake Tana water resources which include fish, and papyrus grass which they harvest, they also have the track of flood plain lands along the shore line which serve as their habitation and farm land. Very few keep animals which they have.

\section{Livelihoods Activities}

The financial capital of the people is a function of livelihood activities in which they are engaged in. In this community because of the fragile physical condition of their environment and other institutional factors, livelihood activities are basically of three types, these are fishing, farming and petty trading. The people have ability to neither save nor access to credit facility as they live their lives from hand to mouth, very few of the old people have access to remittances but not regular contrary to the assumption of the DFID framework. The people either concentrate on one activity or combine two of the three at different time of the year. The study revealed livelihood activities of the people revolve round fishing and farming, as revealed in type of livelihoods activity in Table 1. 27.6\% of the people engaged in fishing alone, fishing and farming account for another $32.5 \%$, farming alone is $7.3 \%$ while petty trading takes $24.4 \%$, the remaining $8.2 \%$ account for those who combine fishing with petty trading or farming with petty trading. The major reason of combining either fishing or farming with petty trading is to maximize their income. The petty trading revolves round what they produce as marketing fish catch, farm product, fuel wood, papyrus grass, with the exception of a few who sells some commodities that are not produced locally such as soap, candle, sweet, matches, oil etc.

A linear stepwise regression was run to determine the relationship and contribution of different livelihoods activity to income at household level. Household incomes in the community depend much on the sales of the product from fishing, farming, fuel wood, and papyrus grass. From Table 1 Monthly income from all livelihoods activity, $45.5 \%$ earn less than 250 Ethiopian birr, another $25.2 \%$ earn between $250-500$ birr with an average of 375 birr as monthly income for that group. $16.3 \%$ claimed to earn between 500-1000 birr, another $9.8 \%$ between $1000-1500$ and $3.2 \%$ in the range of above 1500 birr income per month. From the table a total $70.7 \%$ of the population are in the income group of less than 500 birr. At the time of the research fieldwork when the data was gathered (NovemberDecember 2007) \$1 US Dollar is exchange for 9.14 birr officially, thus by calculation large proportion of the population are earning less than \$30 US Dollar per month, this implies that the percentage of household living on less than \$1 US Dollar per day in the community is very high.

Linear regression model used in this study is of the semi-logarithmic form:

$$
\text { Ly }(M I)=f(x)
$$

Where Ly (MI) is the natural log of Monthly Income (MI-a measure of Financial Capital) measured in terms of income from all livelihood activities and $\mathrm{x}$ is a vector of income generating livelihood activities. The multiple regression is created as a linear 
combination of independent variables, such that Ly (MI) $=\mathrm{c}+\mathrm{b}_{1} \mathrm{x}_{1}+\mathrm{b}_{2} \mathrm{x}_{2}+\ldots+\mathrm{b}_{\mathrm{n}} \mathrm{x}_{\mathrm{n}}$, where $c$ is a constant, the b's are regression coefficients, the x's are independent variables.

Table 2 revealed the variable by variable correlation matrix of the analysis. The 6 independent variables showed correlation with the dependent variable (MI). This is an indication that they all have influence on the financial capital of the people. It is observed that, income from cereals (Ice), income from vegetables (Ive) and income from fish (Ifi) have high positive correlation with Monthly income from all livelihood activities, while livelihood activities (Lac), Income from Papyrus grass (Igra) and Income from fuel wood sale (Iwo) showed low positive correlations. It is of note that all the variables have correlation with each other. The values range from low to moderate correlations, thus all the variables are interrelated and influence the Financial Capital of the people in the community.

Analysis of variance (ANOVA) result showed that there are highly significant differences in means among the variables, which signifies that the set of independent variables has strong influence on the dependent variable-i.e. the Financial Capital of the people in the community (see Table 3 ). For further clarification a step wise regression analysis was run to identify the variables which exalt the most significant impact on the financial capital (MI) of the people. The result identified 3 out of the 6 variables these are income from cereals (Ice), income from vegetables (Ive) and income from fish (Ifi). This was used to generate the regression equation for the relationship as:

$$
\mathrm{MI}=1.333+0.296(\text { Ive })+0.140 \text { (Ifi) }
$$$$
+0.203 \text { (Ice). (See Table 4) }
$$

Where MI- is a measure of Financial Capital; Ive- income from vegetables; Ice- income from cereals and Ifi- income from fish.

\section{Factors of Vulnerability}

Vulnerability is defined as an aggregate measure of human welfare that integrate environmental, social, economic and political exposure to a range of potential harmful perturbations, resulting in poverty, famine, hunger malnutrition and unsustainable livelihoods (Downing,1992; Sen,1981). Apart from income, there are many other factors that co-determine whether an individual will go hungry or living unsustainable live.. Vulnerability rest on a careful disaggregation of the structure of poverty itself, it include both a sensitivity to temporal (i.e. monthly, seasonal, inter-annual) and geographical (i.e. national, regional, village) variability, and also a recognition of how different groups in the society experience risk and mitigate hazards. Chambers (1989) defined vulnerability as the exposure to contingencies and stress and difficulty coping with them. He further identified the two sides of vulnerability as; an external side of risks, shocks and stress to which an individual or household is subject; and an internal side which is defencelessness, meaning a lack of means to cope without damaging loss.

Vulnerability is a multi-layered and multidimensional social space defined by the determinate political, economic and institutional capabilities of people in specific places at specific times, which can be expressed spatially from the local to the regional to the transnational and temporally both as a long-term structural baseline and as a short-term conjunctural condition (Bohle et al 1994). The most vulnerable individuals, groups, classes and regions are those most exposed to perturbations, who possess the most limited coping capacity and suffer the most from the impact of crisis or environmental perturbations (such conditions of marginal lands), and who are endowed with circumscribed potential for recovery. The "Negede Weyto" community fits into a group of vulnerable people as described above.

The report of the FGD identified some of the vulnerability factors affecting the livelihoods of the people in the community. The views of the four FGD converged on external factors affecting their livelihoods apart from their limited capacities; these are land tenure, urbanization, diseases and inaccessibility to health care delivery.

On issue of land the question was raised about the right accessibility to land for farming since farm is a determinant of their 
financial capital. The summary of response read thus:

\section{$>$ We don't have much accessibility to land as the annual flooding of Tana is a problem, \\ $>$ The Government owns the land, they can ask us to quit any time, once the big people apply for the use of the land and they pay per square meter which is beyond our financial capacity. \\ $>$ We plant arable crops they will just give us notice to quit after harvesting of our crops. \\ $>$ That is why we move from one location to the other, we are more of migrants in our own land.}

The rate of urbanization which necessitates physical expansion is a major reason for high demand for land, as such the local people are at disadvantage in the scramble for land for urban development and farming and people on marginal land are the worse for it.

Apart from effect of urbanization on land matters, the FGD groups claimed that urbanization has disrupted the social fabric of their community; these are expressed with the following statements:

$>$ Our young people (male and female) are moving to the city because there is no enough land to cultivate.

$>$ They are engaged in "Saratanya" (Amharic work for servants engaged in menial jobs) and the females in prostitution.

$>$ They come back with deadly diseases (HIV/AIDS, Venereal diseases), sickness and eventual death. A bundle of sorrow for community.

$>$ The disease they brought are transmitted to others in the community

$>$ Stealing is becoming rampant, thief carting away fishing nets and crop harvest.

The above leads to their health conditions as another external factor of vulnerability which are expressed in the following statements:

$>$ Our houses are inadequate we live together in our 'hut' this make the diseases to spread fast.

$>$ We depend on water from the lake so we suffer from water borne diseases a lot-such as, diarrhoea, malaria, typhoid fever, cholera, tuberculosis, skin diseases, river blindness etc.

$>$ The hospital is in the city, more than 3 kilometres, and we don't have enough money to buy drugs, they are too expensive.

$>$ We depend much on our traditional practices which often fail.

$>$ We suffer a lot of infant and adult deaths in this community.

\section{Conclusion}

The findings from the respondents and the FGD report point to the fact that the "Negede Weyto" is facing serious vulnerability beyond their capacity and thus living in an unsustainable livelihoods. In line with the view of Bohle et al (1994) the prescriptive and normative response to vulnerability is to reduce exposure, enhance coping capacity, strengthen recovery potentiality and bolster damage control (i.e. minimize destructive consequences) via private and public means.

The situation in the community is not yet beyond remedy, there is a need for Government and NGOs to come up with intervention programme/ projects to rescue the community from the vulnerability they face. One important thing to them is to secure tenurial right on their farm lands and accessibility to health care delivery at affordable cost if not for free.

They still have some potential capabilities which can be redirected into some other economic sectors to improve their livelihoods. For instance, the fisher men can be assisted with modern engine boat to increase their fishing activity or they can be trained as boat captains for tourism water transportation, since tourism development is the major sector claiming the land along the Lake Tana Shore line, which is the habitation of the people. These and other policy measures 
are necessary to tackle the kind of extreme vulnerability facing people living in marginal

\section{References}

Amhara BFED,(2005) Development Indicators of Amhara Region 2005, Amhara Regional State Bureau of Finance and Economic Development.

Amhara (2005) Ethiopia- Amhara National Regional State Tourist Attractions, Amhara National Regional State Tourism Commission. Bohle H.G., Downing,T.E. and Watts M.J.(1994) Climate Change and Social Vulnerability:Toward a Sociology and Geography of Food Insecurity Global Environmental Change Vol.4 (1) pp37-48

Carney D ( 1999), Introduction to sustainable rural livelihoods: what difference can will make? Department For International Development (DFID), London.

Chambers R. and Conway G. (1992), Sustainable rural livelihoods:Practical concepts for the $21^{\text {st }}$ century. IDS discussion paper; no. 296, Institute of Development Studies, University of Sussex, U.K.

Chambers, R. (1998) Vulnerability, Coping and Policy IDS Bulletin Vol.20 no.2 ppl-7

Downing T.E.(1992) Climate Change and Vulnerable Places: Global Food Security and Country Studies in Zimbabwe, Kenya, Senegal and Chile. Research Report No.1, Environmental Change Unit, University of Oxford,UK.

Rick D.S, Ailsa H., Dan M., Leah,N and Penny W. (2002), Learning about livelihood: Insight from Southern Africa, Periperi and Oxfam, Oxford, UK. lands such as the case of the "Negede Weyto" community.

Sen A.K.. (1981) Poverty and Famines: An Essay on Entitlement and Deprivation, Clarendon, Oxford.

Shackleton S, Shackleton,C and Cousins, D.(2000) The economic value of land and natural resources to rural livelihoods: case studies from South Africa, in At the cross roads: Land and agrarian reform in South Africa into $21^{\text {st }}$ century, edited by Ben Cousins, University of the Western Cape, Cape Town, South Africa.

Titi, V and Singh, N, (1994), Adaptive strategies of the poor in arid and semi arid lands: In search of sustainable livelihoods. IISD working paper, International Institute for Sustainable Development (IISD) ,Winnipeg, Canada.

Turner, S (1998) Course guide in land use and livelihoods, Programme for Land and Agrarian Studies (PLAAS), University of the Western Cape, Cape Town, South Africa.

UNDP (1990), Human Development Report, Oxford University Press, Oxford, UK.

UNDP (2008), Human Development Report, Oxford University Press, Oxford, UK, UNDP.(2008)..www.hdrstats.undp.org/countri es/data_sheets/cty_ds_ETH.html 
Table 1 Frequency and percentage distribution of some variables

\begin{tabular}{|c|c|c|}
\hline Demographic Variables & Frequency & percentage \\
\hline \multicolumn{3}{|l|}{ SEX } \\
\hline male & 95 & 77.2 \\
\hline female & 28 & 22.8 \\
\hline Total & 123 & 100.0 \\
\hline \multicolumn{3}{|l|}{ AGE } \\
\hline$<20$ years & 2 & 1.6 \\
\hline $21-30$ years & 43 & 35.0 \\
\hline $31-40$ years & 51 & 41.5 \\
\hline $41-50$ years & 15 & 12.2 \\
\hline$>$ 50years & 12 & 9.8 \\
\hline Total & 123 & 100.0 \\
\hline \multicolumn{3}{|l|}{ Marital Status } \\
\hline single & 19 & 15.4 \\
\hline married & 75 & 61.0 \\
\hline widowed/widower & 11 & 8.9 \\
\hline divoerced & 9 & 7.3 \\
\hline separated & 9 & 7.3 \\
\hline Total & 123 & 100.0 \\
\hline \multicolumn{3}{|l|}{ Educational Status } \\
\hline none & 58 & 47.2 \\
\hline grade $1-4$ & 33 & 26.8 \\
\hline grade $5-8$ & 24 & 19.5 \\
\hline grade $9-10$ & 4 & 3.3 \\
\hline grade $11-12$ & 3 & 2.4 \\
\hline diploma & 1 & .8 \\
\hline Total & 123 & 100.0 \\
\hline \multicolumn{3}{|l|}{ Number of Children } \\
\hline None & 11 & 8.9 \\
\hline 1 child & 16 & 13.0 \\
\hline 2 children & 18 & 14.6 \\
\hline 3 children & 35 & 28.5 \\
\hline 4 children & 17 & 13.8 \\
\hline 5 children & 10 & 8.1 \\
\hline$>5$ children & 16 & 13.0 \\
\hline Total & 123 & 100.0 \\
\hline \multicolumn{3}{|l|}{ Type of livelihoods Activity } \\
\hline fishing & 34 & 27.6 \\
\hline farming & 9 & 7.3 \\
\hline petty trading & 30 & 24.4 \\
\hline fishing and farming & 40 & 32.5 \\
\hline fishing and trading & 4 & 3.3 \\
\hline farming and trading & 6 & 4.9 \\
\hline Total & 123 & 100.0 \\
\hline \multicolumn{3}{|l|}{$\begin{array}{l}\text { Monthly income from all } \\
\text { economic activities }\end{array}$} \\
\hline$<250$ birr* & 56 & 45.5 \\
\hline 250-500 birr & 31 & 25.2 \\
\hline $500-1000$ birr & 20 & 16.3 \\
\hline $1000-1500$ birr & 12 & 9.8 \\
\hline$>1500$ birr & 4 & 3.2 \\
\hline Total & 123 & 100.0 \\
\hline
\end{tabular}

*Note \$1 U.S Dollar is exchange for 9.14 Ethiopia Birr

(Under a controlled economy) as at the time of this research November-December 2007

Source: Author's Fieldwork 2007 
Table 2: Correlation Matrix of livelihood activities

\begin{tabular}{|c|c|c|c|c|c|c|c|}
\hline & $\begin{array}{l}\text { Monthly } \\
\text { income all } \\
\text { livelihood } \\
\text { activities(MI) }\end{array}$ & $\begin{array}{l}\text { Livelihood } \\
\text { activities } \\
\text { (Lac) }\end{array}$ & $\begin{array}{l}\text { income } \\
\text { from } \\
\text { cereals } \\
\text { (Ice) }\end{array}$ & $\begin{array}{l}\text { income } \\
\text { from } \\
\text { vegetables } \\
\text { (Ive) }\end{array}$ & $\begin{array}{l}\text { Income } \\
\text { from fish } \\
\text { (Ifi) }\end{array}$ & $\begin{array}{l}\text { Income from } \\
\text { Papyrus grass } \\
\text { (Igra) }\end{array}$ & $\begin{array}{l}\text { Income } \\
\text { from fuel } \\
\text { wood sale } \\
\text { (Iwo) }\end{array}$ \\
\hline $\begin{array}{l}\text { Monthly } \\
\text { income } \\
\text { from all } \\
\text { livelihood } \\
\text { activities }\end{array}$ & 1.000 & & & & & & \\
\hline $\begin{array}{l}\text { Livelihood } \\
\text { Activities }\end{array}$ & .335 & 1.000 & & & & & \\
\hline $\begin{array}{l}\text { income } \\
\text { from } \\
\text { cereals }\end{array}$ & .570 & .530 & 1.000 & & & & \\
\hline $\begin{array}{l}\text { income } \\
\text { from } \\
\text { vegetables }\end{array}$ & .600 & .484 & .676 & 1.000 & & & \\
\hline $\begin{array}{l}\text { Income } \\
\text { from fish }\end{array}$ & .459 & -.198 & .046 & -.012 & 1.000 & & \\
\hline $\begin{array}{l}\text { Income } \\
\text { from } \\
\text { Papyrus } \\
\text { grass }\end{array}$ & .219 & .118 & -.404 & -.436 & -.427 & 1.000 & \\
\hline $\begin{array}{l}\text { Income } \\
\text { from fuel } \\
\text { wood sale }\end{array}$ & .247 & .148 & -.208 & -.280 & -.277 & .576 & 1.000 \\
\hline
\end{tabular}

Table 3: ANOVA Result Step wise Regression.

\begin{tabular}{|r|r|r|r|r|}
\hline Model & Sum of Squares & df & Mean Square & Sig. \\
\hline Regression & 74.897 & 3 & 24.966 & 33.047 \\
Residual & 89.899 & 119 & 0.755 & .000 \\
Total & 164.797 & 122 & & \\
\end{tabular}

Predictors: (Constant), income from vegetables, Income from fish, income from cereals

Dependent Variable: Monthly income from all economic activities

\section{Table 4: Regression Results}

\begin{tabular}{|l|c|c|}
\hline Variables & coefficient & t-value \\
\hline (Constant) & 1.333 & 11.923 \\
\hline Income from vegetables & 0.296 & 4.475 \\
\hline Income from fish & 0.140 & 3.110 \\
\hline Income from cereals & 0.203 & 3.068 \\
\hline R. Square & $45.4 \%$ & R. Square(adj.) \\
F Statistics & $33.05 * *$ & $44.1 \%$ \\
\hline ** Significant at the 95\% confidence level
\end{tabular}

** Significant at the $95 \%$ confidence level

Source: Computer output 